\section{Small Native Mammals of Saskatchewan}

\author{
By W. YANCHINSKI \\ Naicam, Sask.
}

THE GOPHER

To begin with, the well known little animal generally referred to as the gopher is not a true gopher but a member of a large clan of burrow ing rodents rightly called the ground squirrels. This particular species is named Richardson's Ground Squirrel (Citellus richardsonii) but is popularly known as Prairie Gopher, Yellow Gopher or just Flickertail-the latter term refers to its habit of

\section{Baby Rabbit}

\section{JUDY CRUICKSHANK, Lumsden}

One day the rake went over a rabbit's nest. Hawks were waiting to grab the young ones, but Dad was able to save one baby. It drank milk from my doll's bottle, four of them a day, when Mom held it. When it was big enough to eat green stuff we let it go in the woods.

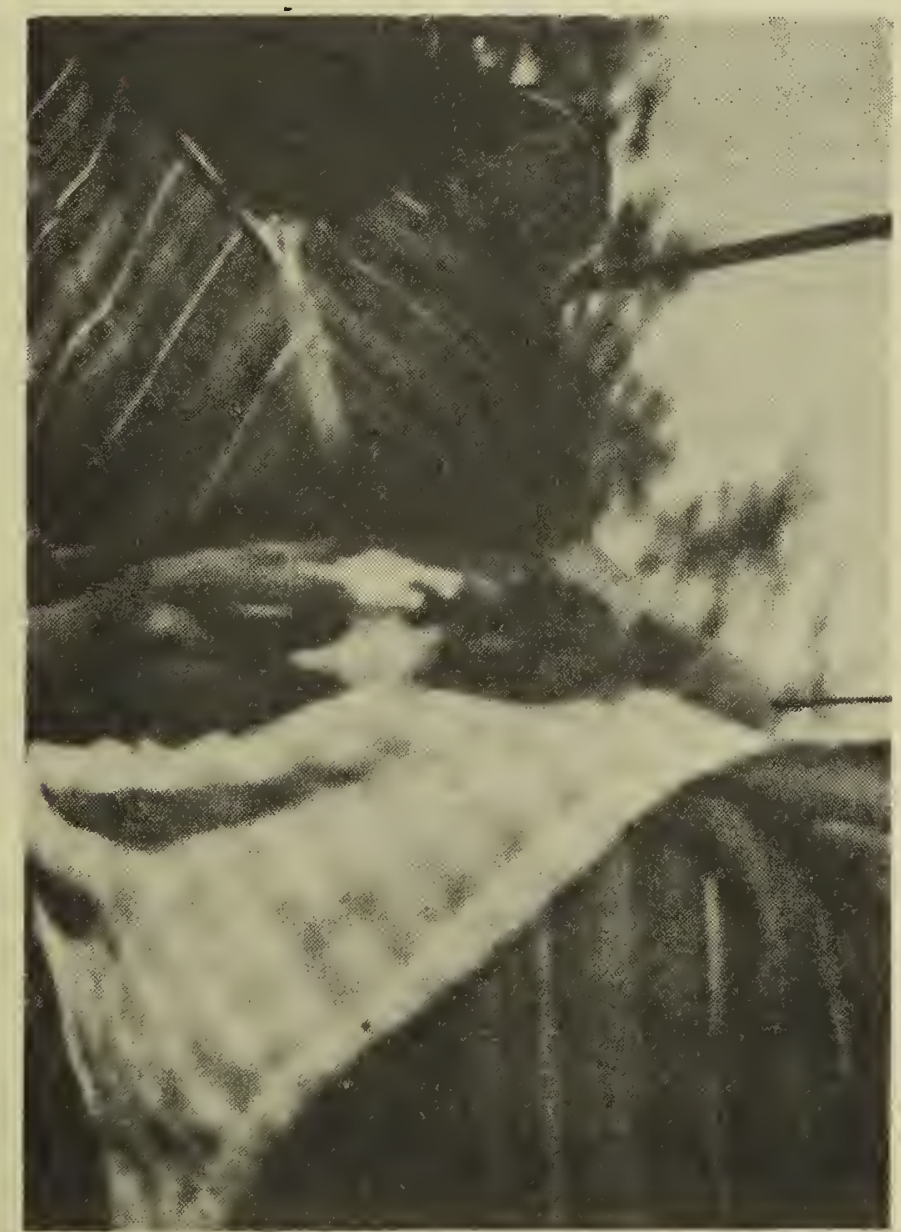

Rescued baby rabbit sucking doll's milk bottle.

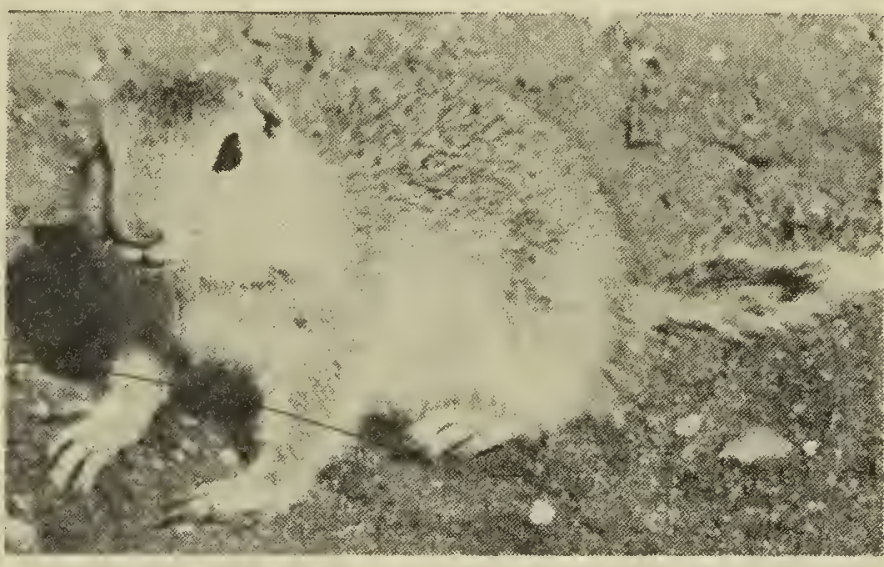

Photo by W. Yanchinski

twitching its tail when excited or alarmed.

The ground squirrel is aptly named for this creature spends more than three-fourths of its life underground and much of this in a profound state of dormancy known as hibernation. The gophers in the colony I observed last summer were practically all underground before the end of August and most of them will not reappear before next April-a full seven months of the year. The curious feature about this phenomenon is why hibernation should start months before winter really begins to make itself felt or for that matter why hibernate at all: after all, other similar animals stay awake more or less throughout the whole bleak season. Tree squirrels sleep only fitfully during the winter, and much the same is true of mice, weasels, and others.

The answer in case of the ground squirrels is found in their food habits. Unlike some of the mice these squirrels cannot convert dry starchy foods into moisture and since a squirrel may never take a single drink in its whole life, it must depend entirely on the succulent green plants to provide the water for its body needs. These plants are plentiful in spring and early summer but as the season rolls on they become dry and woody and much less palatable. During the growing season the squirrel gorges himself on the green growth about him but as he gets fatter and the vegetation less tasty he is inclined to spend more and more time underground. The dry coarse food together with restricted quantity of oxygen in the underground burrow tends to induce the long sleep. Finally he quits eating altogether, 
plugs up the entrance to his winter quarters, curls up into a ball and passes into a state of profound torpor. Hibernation is thus a way of overcoming the seasonal deficiency in diet as well as other unpleasant aspects of the inclement wintry weather.

To a degree, it is just this characteristic that accounts for the animal's destructive habits and has turned man's hand against him. A young gopher, born in spring, must in a short span of about 90 days, not only grow up but accumulate enough fat to sustain life for seven or eight months of underground existence. Then, too, the flickertails are probably more gregarious than any of the other squirrels so if these animals become established in a field of grain their combined destructiveness in a small area is much more apparent. In fairness to these much maligned creatures it should be pointed out that contrary to common belief gophers do not prefer grain to native grasses. Their choice of habitat is dictated primarily by the nature of the terrain; thus I have seen them spread out over a sloping piece of uncultivated land but leave an adjoining field of grain untouched. Generally, a gopher selects a site that is open and well drained.

Here are some squirrel facts that may not be known to our younger readers. Besides green vegetation, the flickertail has a taste for animal foods and will eat mice, insects, and even bodies of his own kind. On the other hand, he is pursued by every sizeable flesh-eater that flies, walks and crawls, covering the whole gamut from owls to rattlesnakes.

It is significant that the gopher has turned out to be a great nuisance in areas where man has been most active in predator control. If we weren't quite so zealous in destroying every last coyote, weasel and hawk, these natural enemies of the gopher would hold him in check, just as they did before white men came along to upset the balance of nature.

Incidentally, the Plains Indians relished ground squirrels which they prepared by roasting in hot coals. While a fat, juicy squirrel may be a tasty tid-bit, it is not a diet that is

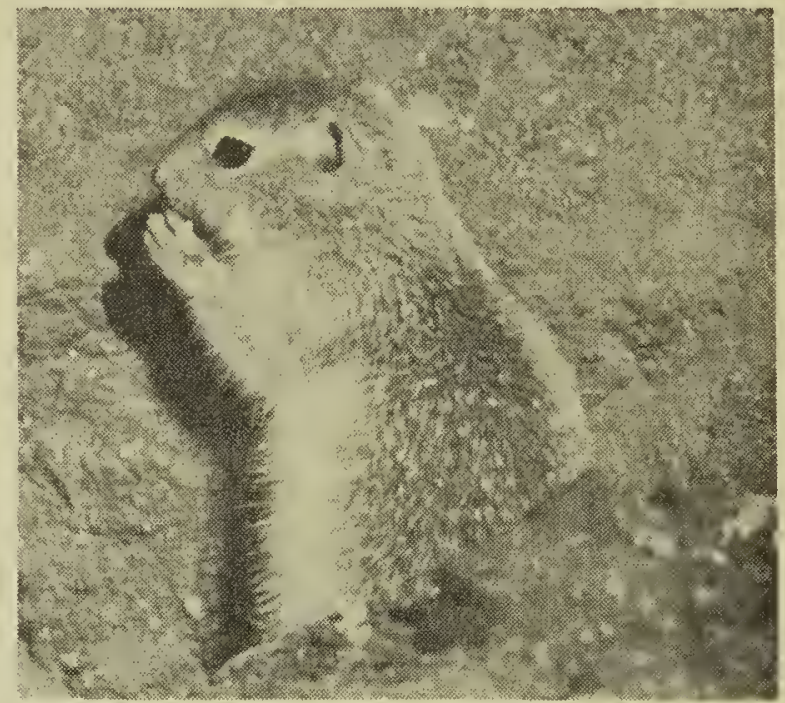

Photo by W. Yanchinski

to be recommended without some reservations. The gophers in some areas may be a definite menace to health and shouldn't be handled, for, through no fault of their own, they have acquired the fleas originally brought over by the old world rats. These insects are carriers of such deadly diseases as the Bubonic Plague and Tularaemia.

Like the Pocket Gopher (the only true gopher in our province) the flickertail has cheek pouches, but these are located internally. All gophers are fond of grain which along with the native seeds and bulbs they store in their winter quarters. In spring, when the weather is bad and food hard to find, a provident squirrel can just stay in bed and feast on the supplies in the well-stocked cupboard.

His nervous and sociable disposition and his intense curiosity mark the prairie gopher as something of a character in the world of wild things. His body set erect on his haunches and his short piercing whistle accompanied by a flick of the tail never fail to stir the schoolboys to action. With a hue and cry the chase is on, but Mr. Gopher is never far from one of his several burrows and may live another day to hurl taunts at his many persecutors. It would be a pity indeed, if in our enthusiasm to destroy everything that has no dollars and cents value, we couldn't tolerate a few flickertails on bits of waste land here and there so that boys and girls of the future could at least get a glimpse of this fascinating feature of the prairie scenery. 